\title{
Diversity of epilithic diatoms in high mountain lakes under the stress of acidification (Tatra Mts, Poland)
}

\author{
B. Kawecka, J. Galas
}

Karol Starmach Institute of Freshwater Biology, Polish Academy of Sciences, 31-016 Kraków, Slawkowska 17, Poland. E-mails : kawecka@zbw.pan.krakow.pl, galas@zbw.pan.krakow.pl

\begin{abstract}
Using the epilithic diatoms as indicators of environmental conditions, 10 lakes in the High Tatra Mountains were characterised with regard to their stage of acidification. The diatom communities were diverse; 210 taxa were found, including 27 species of north and alpine preference. On the basis of cluster analysis, two groups of lakes were distinguished. The first group included shallow, moderately acidified lakes (Dlugi and Zmarzly Gasienicowy lakes), where acidophilous organisms prevailed, with Achnanthes marginulata being the most numerous. The structure of the diatom community in Dlugi lake was stable over 4 years of observations and did not show any progress in acidification. The second group included mostly very deep, non-acidified lakes where circumneutral organisms prevailed, and among them Achnanthes minutissima was dominant in most cases. The diatom community structures mostly confirmed the status of the lakes studied as judged from their water chemistry.
\end{abstract}

Keywords : mountain lakes, Tatra Mts, acidification, indicators, epilithic diatoms.

\section{Introduction}

Investigations on epilithic diatom communities living in lakes of the Tatra Mountains were carried out as part of different EU Projects: AL:PE2 (Alpine Lakes: Paleolimnology and Ecology), MOLAR (Mountain Lake Research), and EMERGE (European Mountain lake Ecosystems: Regionalisation, diaGnostics \& Socio-economic Evaluation). Following the requirements of the EU Water Framework Directive, the aim of these programmes was to assess the status of remote mountain and arctic lake ecosystems throughout Europe. These remote environments, situated in the Alpine and Arctic regions of Europe, are far from local sources of pollution (e.g. land-use or waste-water pollution), and are consequently more sensitive to changes in air quality (acidity and toxic air pollutants). For the EMERGE investigations many alpine lakes situated in high northern latitudes at high altitudes more than $2000 \mathrm{~m}$ have been selected. They are distributed in 12 remote mountain Lake Districts (356 lakes) that cover most of the geographical and environmental gra- dients in Europe. In the Polish part of the Tatra Mountains, 13 lakes were studied.

The Polish part of the Tatra Mts is affected mainly by long-distance emissions from industrial regions in Upper Silesia, Czech Republic and Slovakia. Many papers have been published on the water chemistry of Tatra Mountains lakes showing their various stages of acidification (Wojtan \& Galas 1994, Bombówna \& Wojtan 1999, Galas 2002). The previous algological studies of lakes in the alpine zone of the Tatra referred mainly to the phytoplankton (Wo 1 o s z yńska 1917, 1934, 1935, 1936, 1939, Szklarczyk-Gazdowa 1960, Ettl et al. 1965, Siemińska 1970, Juriš \& Kováčik 1987, Lukavskŷ 1994, Dargocká et al. 1997, Fott et al. 1999), and much less to the benthic organisms, e.g. in sediments, on stones, or associated with aquatic macrophytes (Wasylik 1965, Kawecka 1966, Starmach 1973, Marciniak 1982, 1986, Galas et al. 1996). There are also only few papers dealing with epilithic diatoms of high mountain lakes from other regions (To 1 o t t i 2001, Tolotti \& Cantonati 2002, Šisko \& Kosi 2002). 
In these multidisciplinary projects several parameters of the water chemistry and biota in high mountain lakes have been considered. From the biological aspect, the bacterio-, phyto- and zooplankton, epilithic diatoms, and benthic invertebrates have been studied (Wathne et al. 1997, Wathne \& Rosseland 1999) to understand (AL:PE2) and to measure the dynamic of the response of mountain lakes to acid deposition (MOLAR), to assess the distribution of species and foodweb structure in relation to environmental gradients within and between geographical regions (EMERGE). Diatoms are good indicators of environmental conditions, often used in water quality assessment (Whitton et al. 1991, 1996, Van Dam et al. 1994, Prygiel et al. 1999).

The aim of the present study was to assess the ecological status of 10 lakes situated in the High Ta $\mathrm{r}$ a
Mountains, with special regard to their stage of acidification, by using epilithic diatoms as indicators of environmental conditions against the background of water chemistry data.

\section{Study area}

The Tatra Mountains are the highest part of the Carpathian massive $(2599 \mathrm{~m})$ situated on the border between Poland and Slovakia. The investigations, presented in this contribution were carried out in the High Tatra - the eastern part of the mountain range. Ten lakes were selected, located in the alpine zone (the timber line lies at an elevation of about $1550 \mathrm{~m}$ ), in the area of the Five Polish Lakes Va 11 e y, Rybi Potok Va 11 e y, and Gasienicowa Valley (Fig. 1). The catchment is composed of granite. The lakes investigated are situated at al-
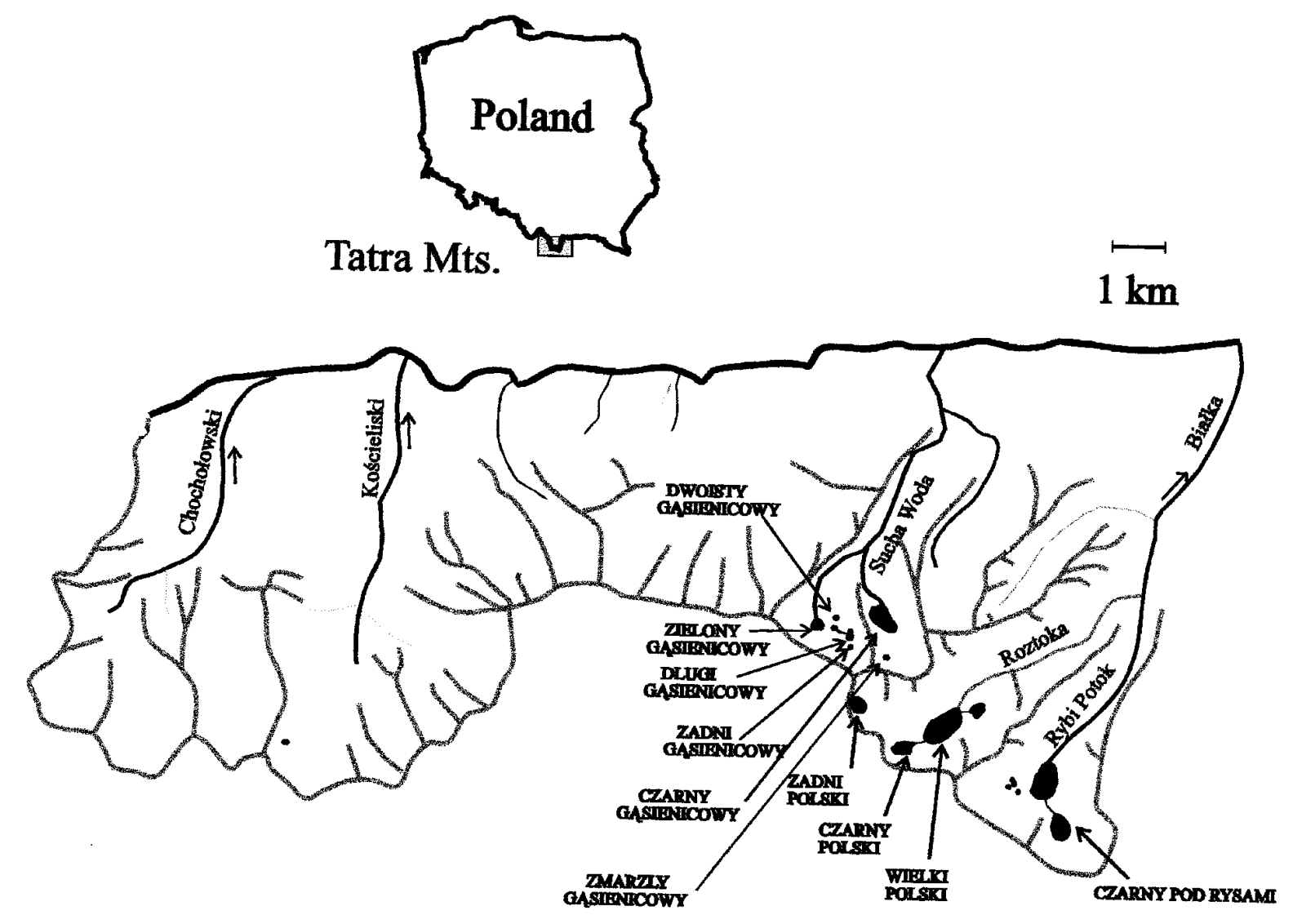

Fig. 1. Localisation of the studied lakes. 
titudes from 1580 to $1890 \mathrm{~m}$ above sea level and differ in size (Table 1). The lake shorelines are rocky and only on the bottom of the Dhugi Gasienicowy lake the moss Warnstorfia exannulata (Schimp) Loeske develop extensively. Most of the lakes are filled with water throughout the year. They are fed mainly by precipitation and melting snow, but are also supplied by numerous springs and water draining through the rocky catchment. Only Dwoisty Gasienicowy (Eastern) lake, which is fed by a surface inflow of water coming mainly from melting snow, has an underground outflow which causes the complete disappearance of water under the snow cover in winter. The duration of the ice cover is 5-8 months.

Precipitation in the Tatra Mountains is mainly low in winter and higher in summer. The highest monthly input of water was recorded in June 1997 during a big flood (Galas 2002). The atmospheric deposition samples from the area of the Gasienicowa Valley were mostly acidic; in $80 \%$ of samples the $\mathrm{pH}$ varied from 4.0 to 4.5 ; sulphate and nitrate concentrations were especially high (Table 2).

\section{Methods}

Precipitation was collected weekly in the Gasienicowa Va 11 e y, while water samples were collected from the surface (10-20 cm depth) above the deepest point of each lake, in September 2000. Both lake water and precipitation samples were analysed according to the methods used in the EU programmes (The MOLAR Water Chemistry Group 1999). The epilithon samples from 10 lakes were collected once in September 2000. Only in the Dhugi Gasienicowy lake studies were carried out for several years. In this case the material was

Table 1. Morphometric characteristics of the studied lakes.

\begin{tabular}{|c|c|c|c|c|c|c|c|c|}
\hline 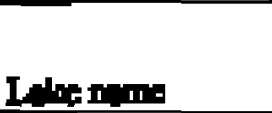 & 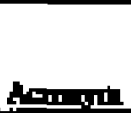 & Ant & 4 & (ii) & ditiditis & mord & pind & Litis \\
\hline 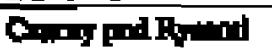 & 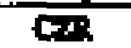 & LE: & 2954 & 764 & 41 & 5 & 12 & 5 \\
\hline $2+101$ & ZHP & Fon & 6 & 326 & 0 & 50 & 10 & 0 \\
\hline 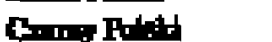 & 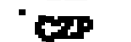 & 172 & 127 & 34 & 41 & $\mathbf{5}$ & 11 & $\mathbf{3}$ \\
\hline Trfiptis & TIIP & yes & 94.14 & H.3 & 24 & 10 & 20 & a \\
\hline 2 det & 240 & ILs & 059 & 80 & $a n$ & 95 & 4 & $\Delta$ \\
\hline Inthom & mitr & $\mathbf{M H}$ & 011 & 17 & DrTt & 9 & 3 & 4 \\
\hline 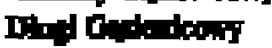 & DHA & 154 & 16 & 106 & al & $\mathbf{s}$ & 10 & 3 \\
\hline 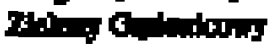 & $2 G$ & $16 \%$ & 3, & 13.1 & at & 6 & $\mathbf{1 5}$ & 3 \\
\hline 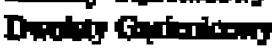 & Drith & 14t5 & 14 & 92 & an & 0 & 10 & 0 \\
\hline 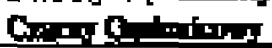 & $\infty$ & ifos & 17.7 & 510 & 1.7 & $\theta$ & $\mathbf{L}$ & 5 \\
\hline
\end{tabular}

Table 2. Ions concentration ( $\mu$ eq. $\left.\mathrm{l}^{-1}\right)$ in atmospheric deposition.

\begin{tabular}{|c|c|c|c|c|c|c|c|c|c|c|}
\hline Yor & $\begin{array}{l}\text { Votwis } \\
\text { (min) }\end{array}$ & $\mathbf{F} \mathbf{H}$ & 0 & Ma & $\mathbf{M n}$ & $\mathbf{X}$ & NH4 & $\mathbf{1 0}$ & $\mathbf{C}$ & 50 \\
\hline $1909 \mathrm{a}$ & 945 & 435 & 17 & 4 & 8 & 10 & $3 t$ & 3 & 16 & 76 \\
\hline 19940 & 136 & $-4,52$ & 17 & 4 & 7 & 3 & 21 & 24 & 9 & 57 \\
\hline $19 \%=$ & 1367 & 4.57 & 21 & 4 & 11 & 21 & 31 & $\mathbf{n}$ & 29 & 51 \\
\hline 1954tor h & I6:4 & 4.24 & 16 & 5 & 4 & - & 24 & 28 & $=$ & 79 \\
\hline 190/199t b & 100 & 4.6 & $\mathbf{E}$ & 3 & 6 & - & 19 & 23 & - & 28 \\
\hline
\end{tabular}

a: Lydersen et al.1997 ; b: The MOLAR Water Chemistry Group (1999) 
collected once a year in October of 1993 and 1994, in August and October of 1996, and in July and September of 1997 . Usually 5 samples were taken from the bottom at ca. $40 \mathrm{~cm}$ depth, at different places along the lake shore. In July 1997, because of a much higher water level, assistance was provided by divers and the material collected at 1-2 m. Diatom epilithon was brushed from the whole upper surface of the several stones and was preserved with Lugol's solution. Subsamples for diatom analysis were macerated in sulphuric acid cleaning mixture, and then washed several times with distilled water by centrifugation. The cleaned diatoms were embedded in «Pleurax» synthetic resin (refractive index 1.75). The diatom taxa were identified and counted using a Nikon E 600 microscope.

The taxonomy of diatoms followed Krammer \& Lange-Bertalot (1986-1991a, b), Round et al. (1990), Krammer (1992), Lange-Bertalot \& Moser (1994), Lange-Bertalot \& Metzeltin (1996), Lange-Bertalot et al. (1996), and Flower \& Jones (1989). For quantitative elaboration of diatoms, a minimum of 250 valves per sample were counted along random transects. The percentage share of species in the communities was then calculated. The taxa with relative abundance lower than $5 \%$ were designated as sporadic, the others as numerous.

The diversity index was calculated according to Shannon \& Weaver (1949) formula, and evenness according to the formula of Pielou (1975) The division of diatoms into ecological groups with respect to water
$\mathrm{pH}$ was conducted following the classification system of Van Dam et al. (1994). Diatom community results were processed using cluster analysis (Pearson correlation and average linkage methods).

\section{Results}

\section{Lake water chemistry}

The waters of the lakes studied were very weakly mineralised with low calcium and magnesium contents, and low alkalinity and conductivity values (Table 3). They were ultra- oligotrophic with very low contents of ammonium and nitrate. The $\mathrm{pH}$ varied from 5.7 to 7.0. Two groups of lakes depending on $\mathrm{pH}$ and ANC (Acid Neutralising Capacity), were distinguished, i.e. slightly acidified water bodies and nonacidified deep lakes (Table 3). The melting snow affects their water chemistry causing a decrease in alka$\mathrm{l}$ i n i t y, pH, and major ion concentrations. Fluctuations of $\mathrm{pH}$ were observed during the year. The average $\mathrm{pH}$ value of the Dlugi Gasienicowy lake was 5.9, but during snow melt it dropped to 5.1 (Galas 2002). The lowest value of $\mathrm{pH}$ in Zielony Gasienicowy lake was recorded after snow melt period (4.2-4.5), while later on it slowly increased, reaching maximum values of 6.26.5 in summer (Kownacki et al. 2000). In Dwoisty Gasienicowy lake the $\mathrm{pH}$ fluctuated from 4.2 in June to 6.5 in August (Kownacki et al. 2002).

Table 3. Chemical characteristics of the studied lakes (conductivity $\mu \mathrm{S} . \mathrm{cm}^{-1}$ at $25^{\circ} \mathrm{C}$; concentrations $\mu$ eq. $\mathrm{l}^{-1}$ )* . ANC $=\mathrm{Acid}$ Neutralising Capacity. Differentiation on two group of lakes (slightly acidified, non acidified) according to Fott et al. (1994).

\begin{tabular}{|c|c|c|c|c|c|c|c|c|c|c|}
\hline & DH & OnI & $A^{\prime \prime}$ & rit4 & Ca & $\mathrm{MS}$ & $\mathbf{5 4}$ & $\mathbf{M B}$ & $\mathbf{E}$ & $\operatorname{Mit}$ \\
\hline & & & & & & & & & & \\
\hline y & 19 & 15 & 16 & 19 & 7 & 8 & 4 & 47 & 50 & 5 \\
\hline & $\mathbf{A x}$ & $\mathbf{1 5}$ & $\ddot{z}$ & 3.1 & $\boldsymbol{H}$ & 7 & 46 & $\mathbf{H}$ & 48 & 1 \\
\hline rapr & 38 & $\mathbf{1 3}$ & $t$ & 98 & 61 & 14 & 4 & 31 & 48 & 20 \\
\hline $2 \cdot 1+1$ & 51 & 24 & 77 & $9 n$ & 91 & 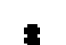 & 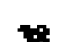 & 27 & 7 & 7 \\
\hline 2nd and & 64 & $\mathbf{1}$ & $M$ & 19 & 9 & 10 & 46 & 4 & 51 & 31 \\
\hline $\mathrm{B}_{\mathrm{p}} \mathrm{G}$ & 64 & 17 & 4 & 1,6 & 111 & 6 & 47 & 4 & 50 & 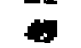 \\
\hline T: & 6.6 & 16 & 6 & 1.2 & $\mathbf{a}$ & 14 & $\mathbf{B}$ & 14 & 51 & 5 \\
\hline W!4 & 6.7 & 17 & $\boldsymbol{M}$ & 1.4 & 1ns. & 10 & 40 & 19 & 35 & $\boldsymbol{T}$ \\
\hline$F+G$ & 67 & 10 & $\mathbf{I}$ & 1.6 & 10.5 & 13 & $\mathbf{A r}$ & 14 & 4.7 & 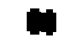 \\
\hline 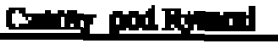 & 7.0 & 2 & 137. & 10 & 15 & 12 & 5 & 31 & $\mathbf{5 3}$ & 12 \\
\hline
\end{tabular}

* Stuchlik unpublished data 


\section{The structure of the diatom communities}

210 diatom taxa were found in the material collected, and among them 27 species of north and alpine preference (Table 4). The most numerous genera were: Navicula (26 taxa), Eunotia (26), Cymbella (19), Ach nanthes (19), Fragilaria (16), and Pinnularia (13). The highest species diversities (H') were observed in Zadni Polski and Zielony Gasienicowy lakes, while the lowest was in Czarny pod Rysami lake.

On the basis of comparative analysis of diatom communities investigated here, two groups of lakes were distinguished (Fig. 2). Zmarzły and Długi Gasienicowy lakes belong to group I whose diatom communities indicated a slightly acidic environment. Similarly, the values of $\mathrm{pH}$ (5.9-6.1) and ANC (5-13) in these lakes classified them as intermediately acidified lakes. In their diatom communities, from 38 to 52 taxa were found, the diversity indices were medium and similar in both lakes (H' 3.2-3.6; evenness 0.63). Acidophilous organisms dominated (Fig. 3), with Achnanthes $m$ a rginulata, $A$. helvetica, $A$. helvetica var. minor being the most numerous taxa (Fig. 4).
The 8 remaining lakes belonged to the second group, whose diatom communities did not indicate any acidification, as it was confirmed in most cases by their water chemistry. Only Dwoisty Gasienicowy lake had a slightly acidic character (Table 3 ). In other lakes, $\mathrm{pH}$ values varied from 6.3 to 7 and the ANC values from 29 to 124 which allowed them to be classified as nonacidified lakes. The numbers of taxa in these lakes ranged from 29 to 72 , with fairly various diversity index values (H'1.6- 4.45; evenness 0.34-0.73). Circumneutral forms predominated, but alkaliphilous and acidophilous species were also fairly numerous, especially in Dwoisty Gasienicowy lake (Fig. 3). Achnanthes mi nutissima formed large populations, especially in Czarny pod Rysami lake, where it comprised approximately $80 \%$ of the whole diatom community, which showed the lowest number of species and index of dive r s it y. In other lakes, Cymbella minuta, Fragilaria capucina gracilis group, Fragilaria pinnata, species belonging to the genus Achnanthes (Achnanthes cur tissima, A. flexella, A. marginulata), and Diatoma eh renbergii were locally fairly numerous (Fig. 4).

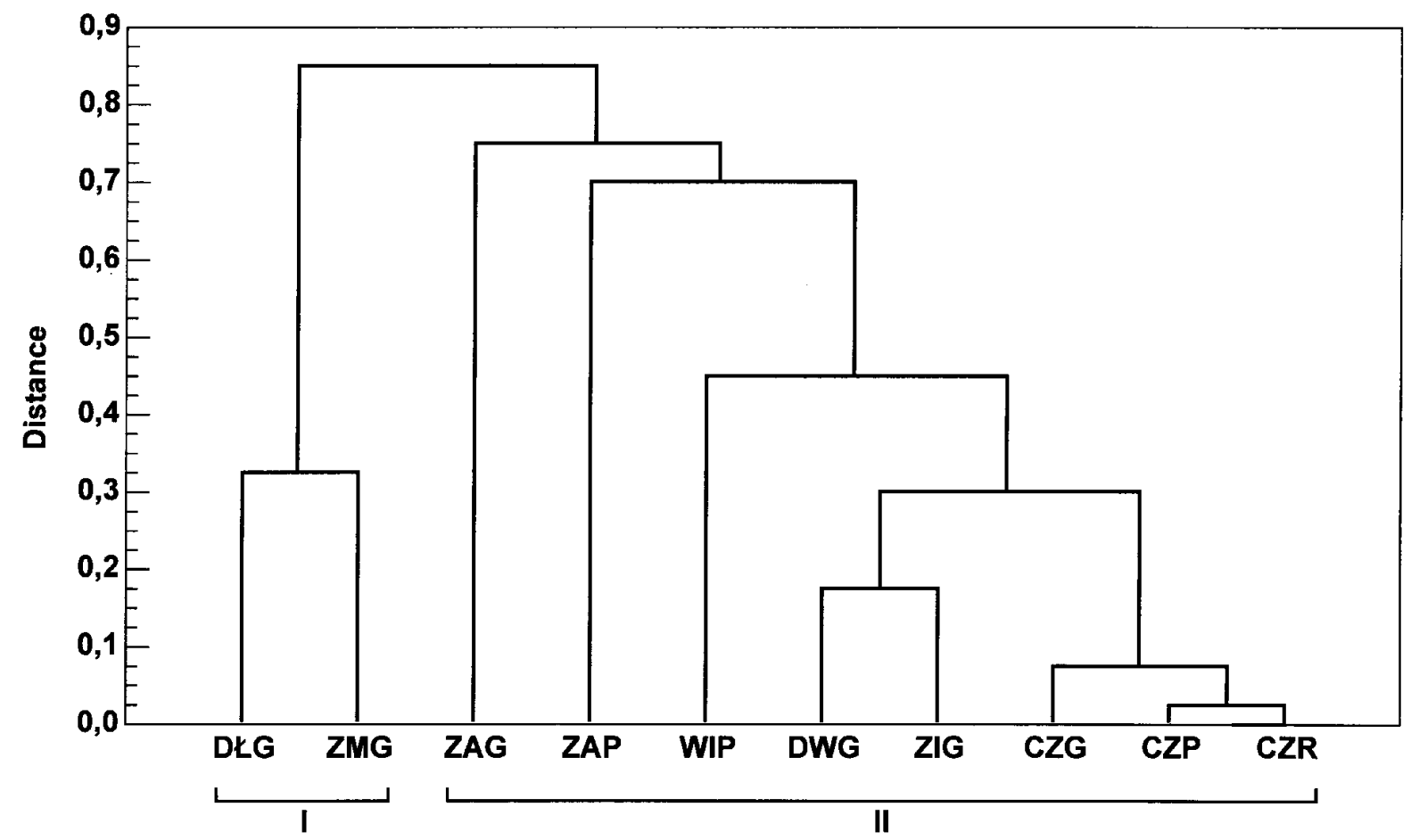

Fig. 2. Dendrogram of similarities between investigated lakes; group I: intermediately acidified lake, group II: non-acidified lakes (abbreviations : see Table 1). 
Table 4. List of epilithic diatoms of investigated lakes; $++=$ numerous species $(>5 \%),+=$ sporadic species, $*=$ species with north and alpine preferences.

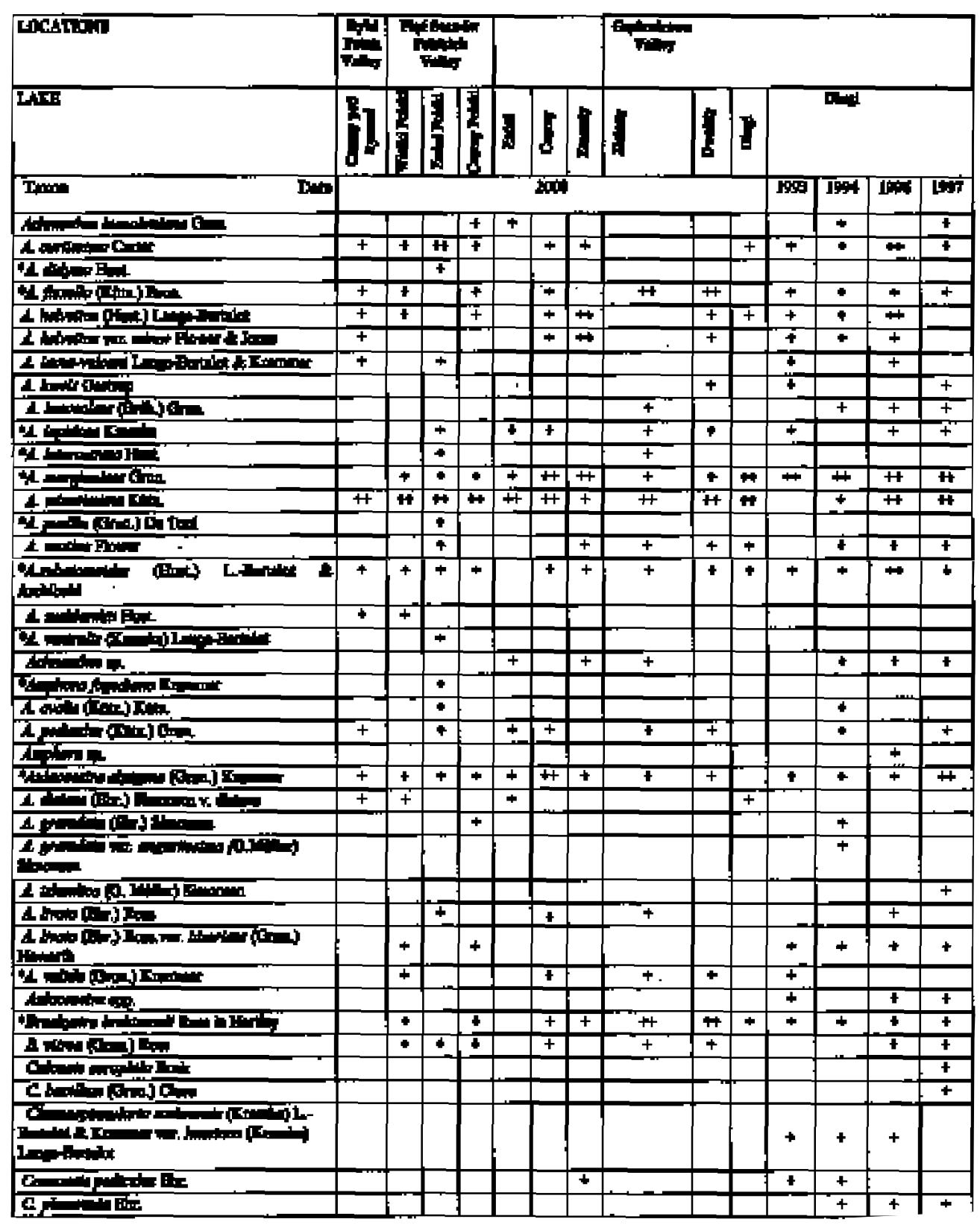


Table 4. (Continued).

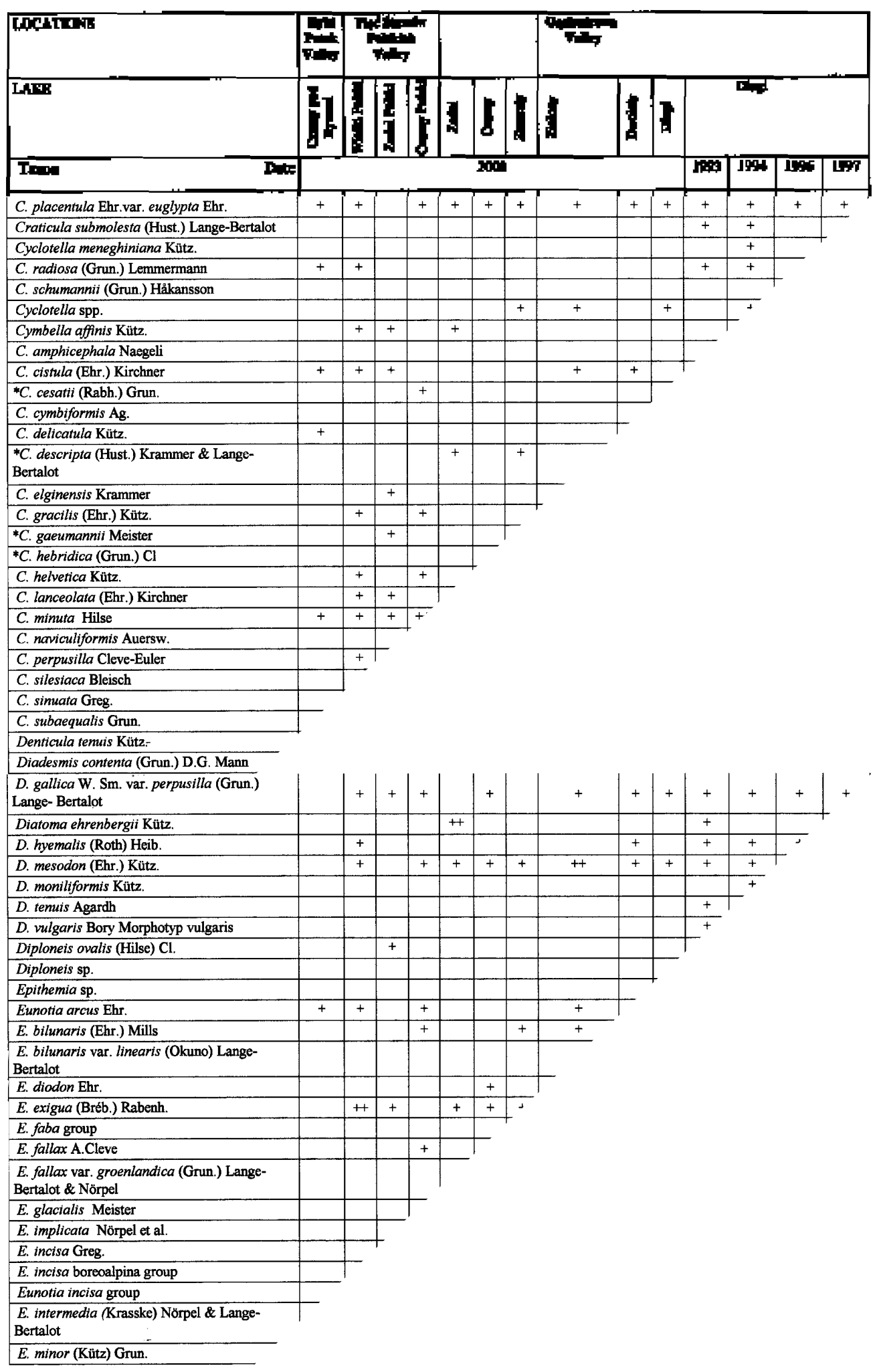


Table 4. (Continued)

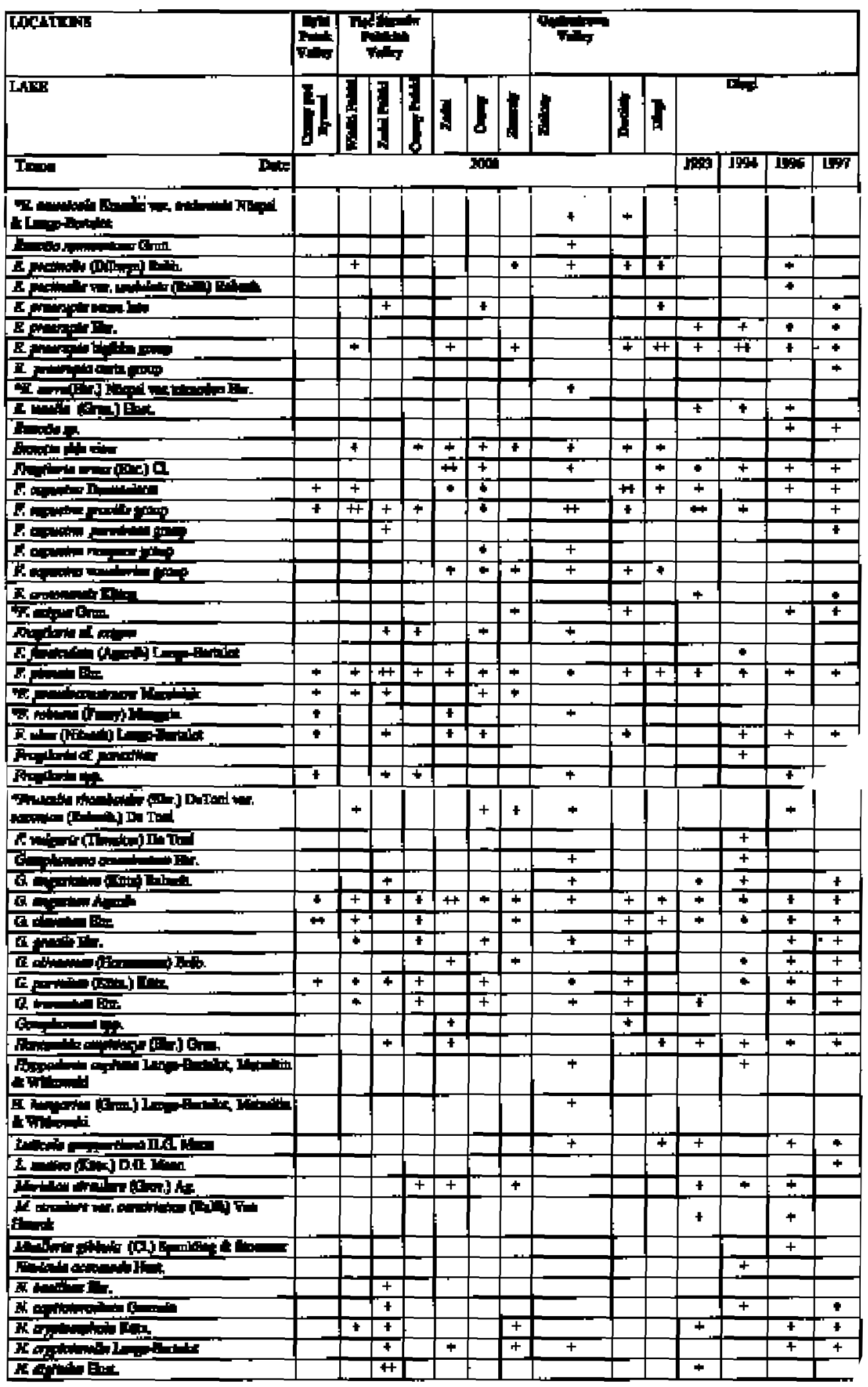


Table 4. (Continued).

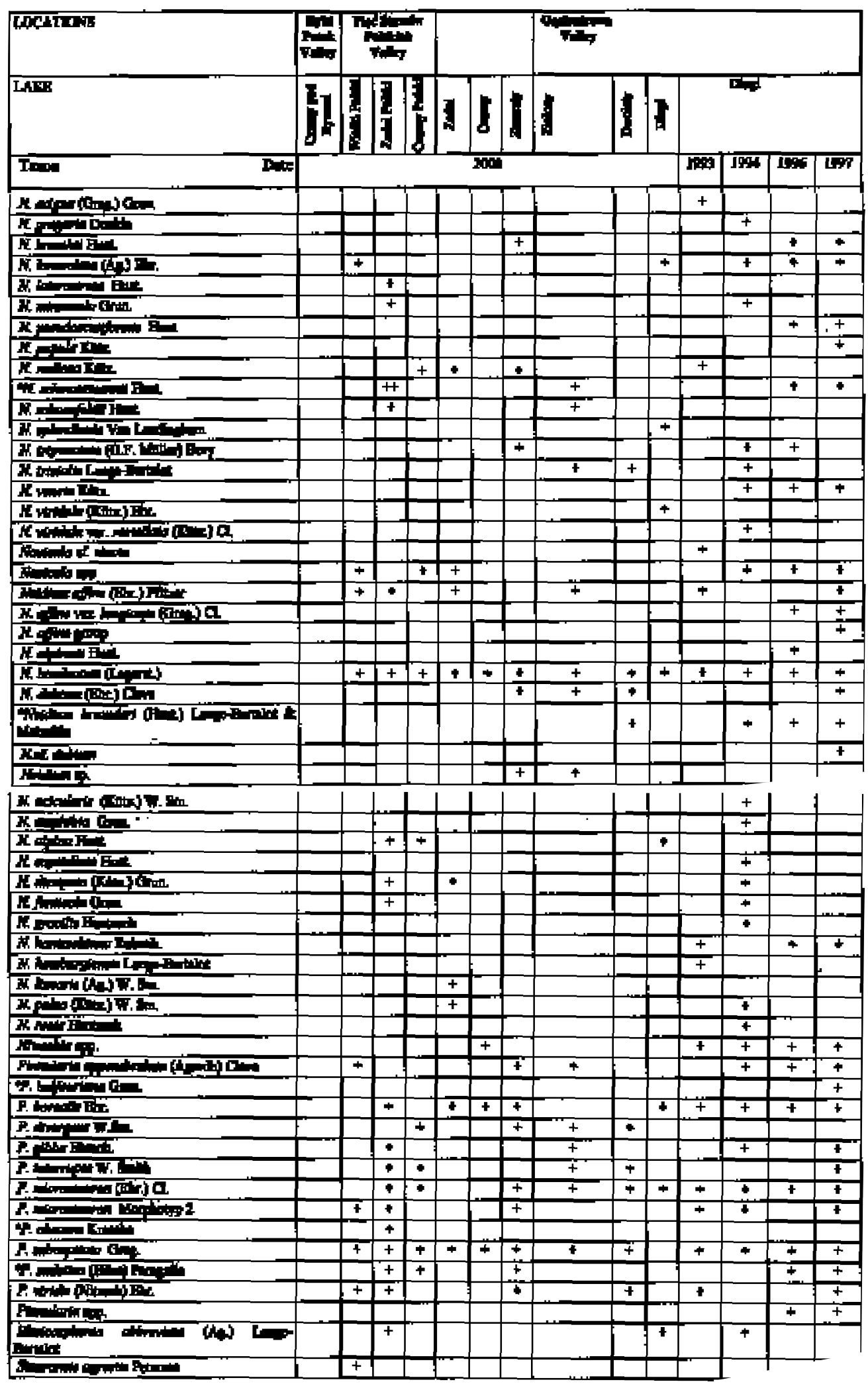




\begin{tabular}{|c|c|c|c|c|c|c|c|c|c|c|c|c|}
\hline WRAtws: & 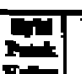 & & & & & 9 & & & & & & \\
\hline LAER & & & & & & & & & & क्त & & \\
\hline T:Do & & & & & (1) & & & & m| & 1994 & LEF & $\mathbf{L F}$ \\
\hline 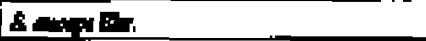 & & +1. & & & & + & -1 & & + & & +7 & + \\
\hline 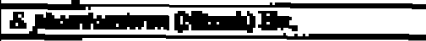 & & 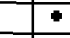 & & & & & + & + & + & & & \\
\hline sonetr & & & $\cdot$ & & & & & & & $\mp$ & & $\bar{t}-$ \\
\hline 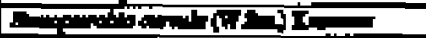 & & & & & & & & & & $\mp$ & & \\
\hline 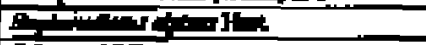 & & & + & & & & & + & & & \pm & \\
\hline Interse & & & & & & & & & & & & $\bar{t}$ \\
\hline 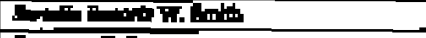 & & & & & & \pm & E & & 4 & & & \\
\hline QDen & & & & & & & & & & & & \pm \\
\hline Bar & & + & I & & & & 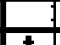 & & 4 & + & & \\
\hline
\end{tabular}

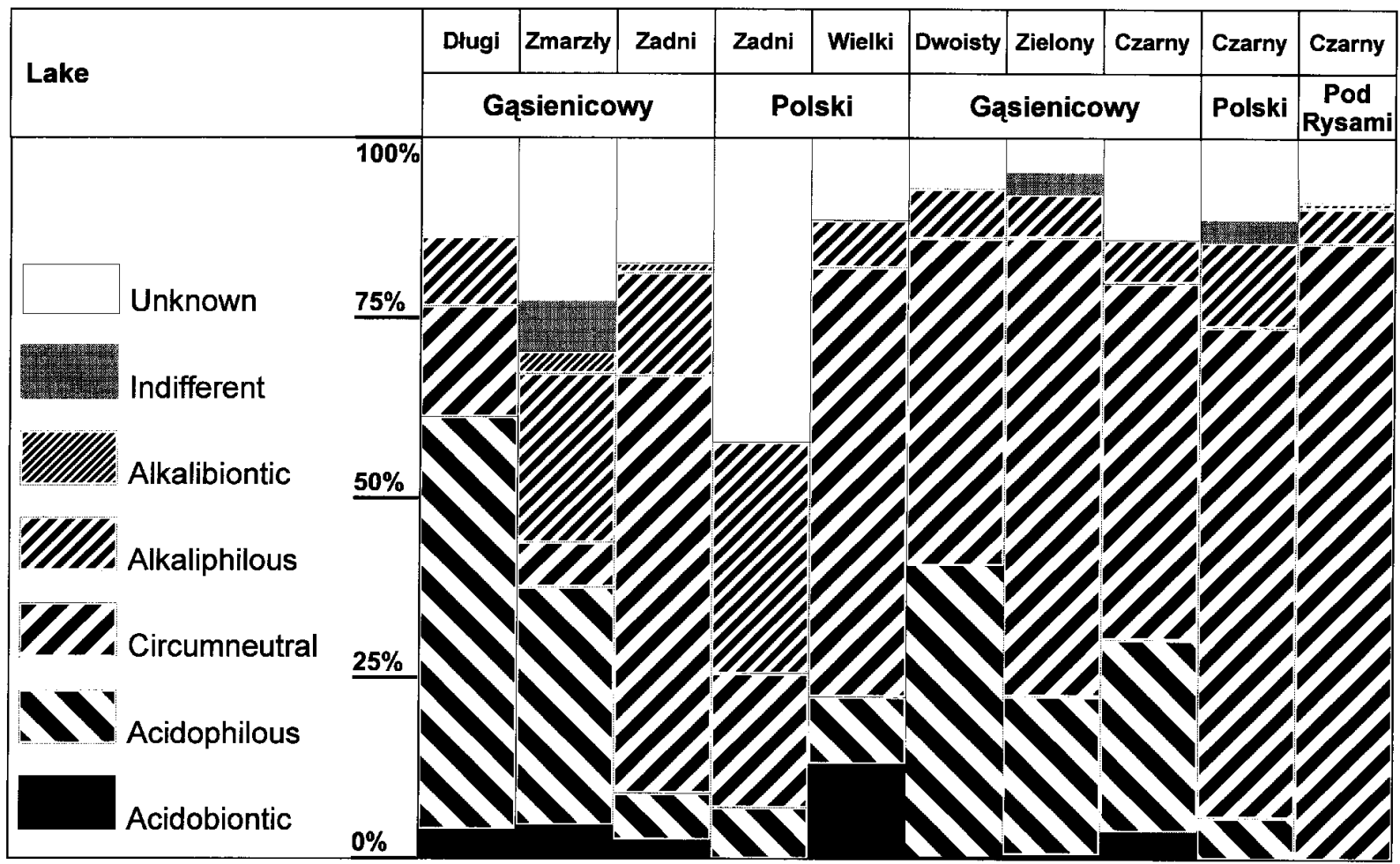

Fig. 3. Relative abundance of diatoms based on the $\mathrm{pH}$ classification system in investigated lakes. 


\begin{tabular}{|c|c|c|c|c|c|c|c|c|c|c|}
\hline \multirow{3}{*}{ 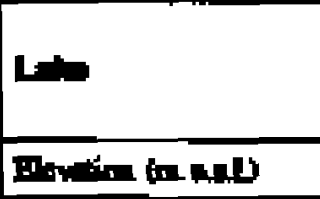 } & \multirow{2}{*}{\multicolumn{3}{|c|}{ Dop baty }} & \multirow{2}{*}{\multicolumn{2}{|c|}{ 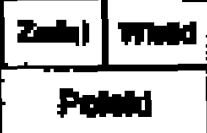 }} & & 2ling & exing & \multirow{3}{*}{$\frac{f+1}{\operatorname{trn}}$} & \multirow{3}{*}{$\frac{c+4}{104}$} \\
\hline & & & & & & \multicolumn{3}{|c|}{ 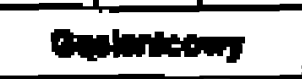 } & & \\
\hline & Ind & $1 \mathrm{TAT}$ & 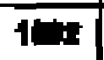 & 19:4 & 104 & 18 & AM & 10 & & \\
\hline Dis and & Ian & $\mathbf{t}$ & 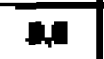 & nat & $\pi$ & $\mathbf{A t}$ & Ant & are & MA & $\mathbf{r a t}$ \\
\hline F & 40 & 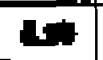 & 25 & 61 & a:s & $\overline{5 T}$ & 67 & 10 & $4 \mathbf{n}$ & $\boldsymbol{r a s}$ \\
\hline Mrita ofteris & $\mathbf{m}$ & 8 & 4 & $\mathbf{7 t}$ & 4 & $\mathbf{a}$ & ta & 4 & 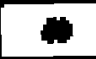 & $\mathbf{3}$ \\
\hline Dhathory & 14 & 20 & mPt & 41 & $\mathbf{3 4}$ & $A F$ & 41 & 24:5 & 21 & $1 \mathrm{~S}$ \\
\hline Fn:Den & $\mathbf{H i}$ & $\infty$ & 4 & At: & 4 & $\boldsymbol{\mu N}$ & 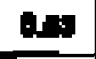 & nis & an & 02 \\
\hline \multicolumn{11}{|l|}{ 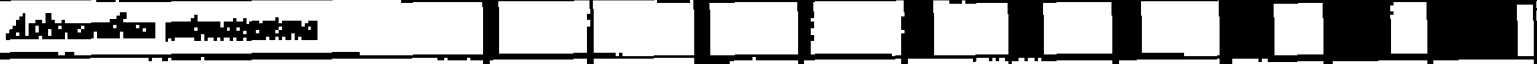 } \\
\hline \multicolumn{11}{|l|}{ CHamb ats } \\
\hline \multicolumn{11}{|l|}{ Achophar ming } \\
\hline \multicolumn{11}{|l|}{ 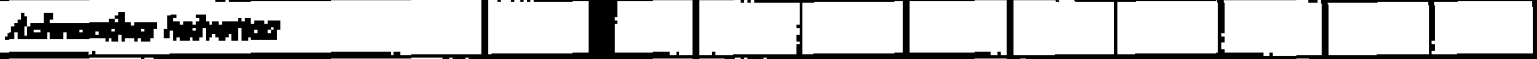 } \\
\hline \multicolumn{11}{|c|}{ 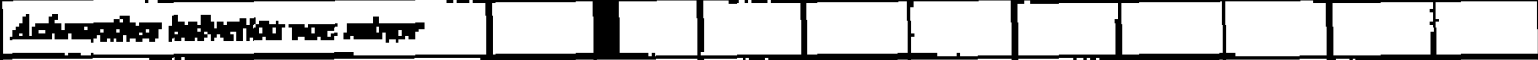 } \\
\hline \multicolumn{11}{|c|}{ 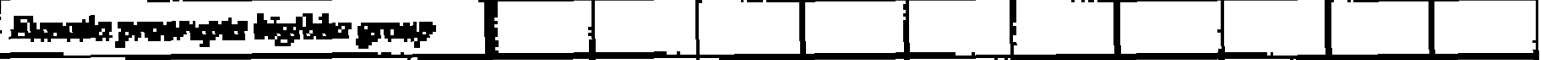 } \\
\hline \multicolumn{11}{|l|}{ 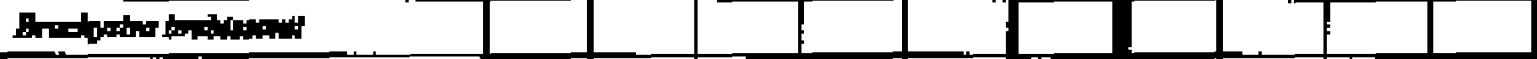 } \\
\hline \multicolumn{11}{|l|}{ 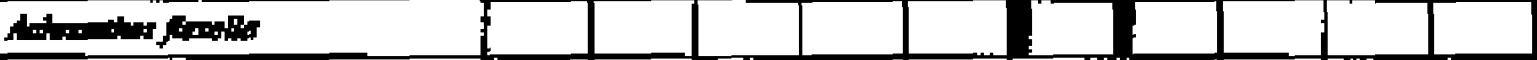 } \\
\hline \multicolumn{11}{|l|}{ Dnwathing } \\
\hline \multicolumn{11}{|l|}{ 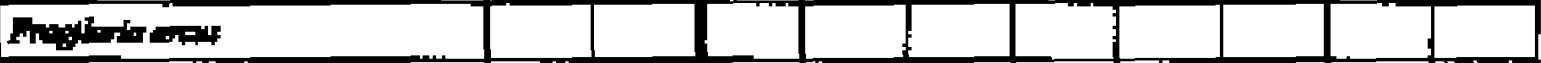 } \\
\hline \multicolumn{11}{|l|}{ 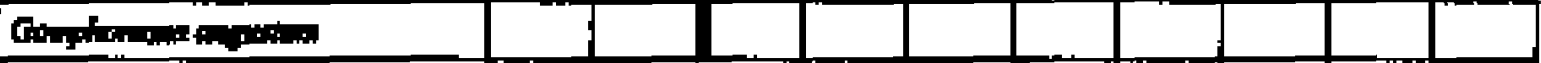 } \\
\hline \multicolumn{11}{|l|}{ 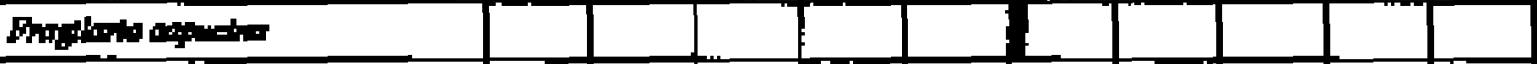 } \\
\hline \multicolumn{11}{|l|}{ 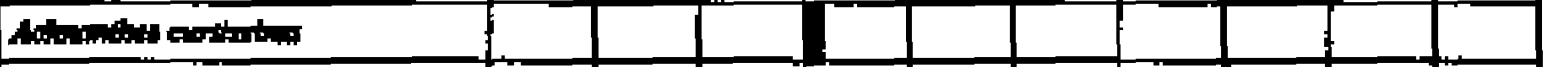 } \\
\hline \multicolumn{11}{|l|}{ 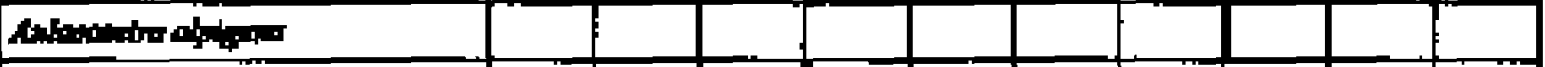 } \\
\hline \multicolumn{11}{|l|}{ 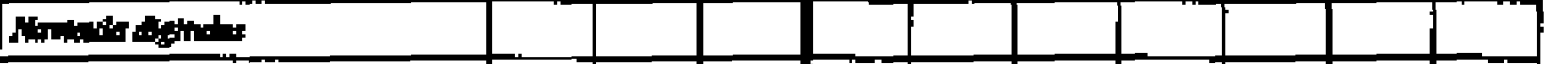 } \\
\hline \multicolumn{11}{|l|}{ 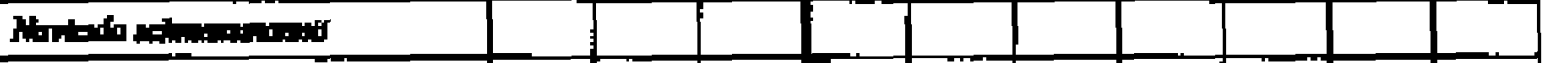 } \\
\hline \multicolumn{11}{|l|}{ Fhoplotapitat } \\
\hline \multicolumn{11}{|l|}{ 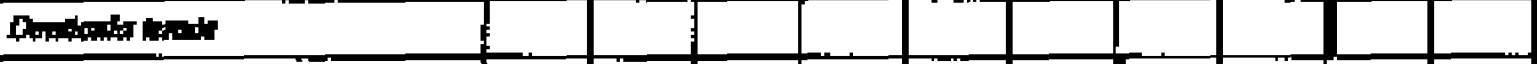 } \\
\hline \multicolumn{11}{|l|}{ 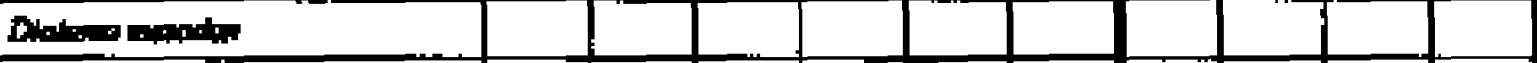 } \\
\hline \multicolumn{11}{|c|}{ 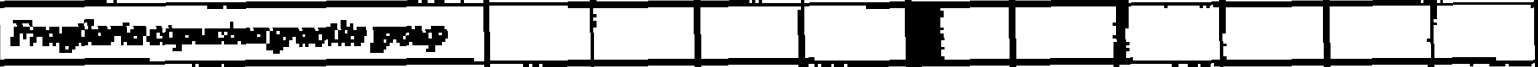 } \\
\hline \multicolumn{11}{|l|}{ 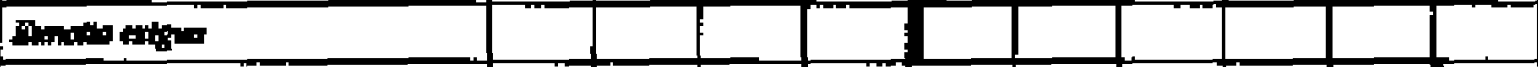 } \\
\hline 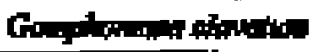 & & & & & & & & & & \\
\hline
\end{tabular}


$\mathrm{S} t \mathbf{r} u \mathrm{c} t \mathrm{u}$ re of the diatom communities in Dyugi Gasienicowy lake during the years 1993-1997

Observations over four years indicated that diatom community structure in the Długi Gasienicowy lake was stable and did not show any change with respect to acidification. 171 diatom taxa were found, most of the species forming small populations. The diversity index was high and similar throughout the period of the investigations. Acidophilous groups of species dominated throughout (Fig. 5), the most abundant population being formed by Achnanthes marg in ulata. Other Ach nanthes species as Achnanthes minutissima, A. subato moides, A. curt is s i m a were also fairly numerous as well as Cymbella minuta and Aulacoseira alpigena (Fig. 6).

\section{Discussion}

The epilithic diatom communities and water chemistry of the lakes studied indicate that the majority of the
Tatra lakes are not acidified (Tab. 3, Fig. 3, 4). Only two of them, shallow Diugi and Zmarzly Gasienicowy lakes, show an intermediate level of acidification. In those lakes a group of acidophilous diatoms prevailed with Achnanthes marg in u la ta being dominant, reaching a particularly high percentage share of the diatom community in Długi Gasienicowy lake. Ach nanthes marginulata is a species characteristic of oligotrophic waters, preferring weakly to moderately acidic waters (Krammer \& Lange-Bertalot 1991 b). It is also numerous in small acidic Tatra water bodies such as Mnichowy Staw ponds (Kawecka unpublished data) which have a pH of 4.8-5.2 (Dumnicka \& Galas 2002), as well as in lakes of several other high mountain regions e.g. in Norway, Scotland, Italy, and France (Wathne et al. 1995) whose pHs ranged from 4.5-6.1 (Mosello et al. 1995). It is worth noting that Achnantes marginulata is characteristic of the north-alpine areas (Krammer \& Lange-Bertalot 1991b) and is an endan-

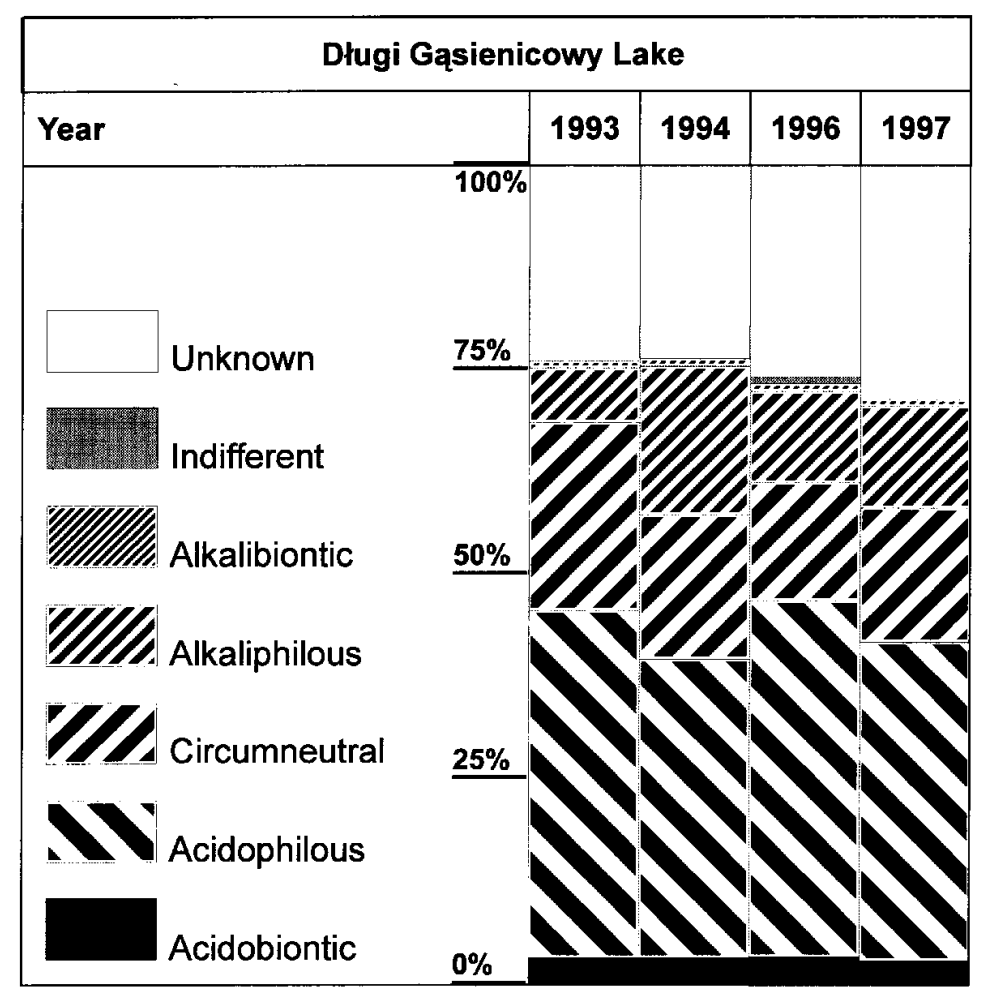

Fig. 5. Relative abundance of diatoms based on the $\mathrm{pH}$ classification system in Długi Gasienicowy lake in the years 1993-1996. 


\begin{tabular}{|c|c|c|c|c|}
\hline \multicolumn{5}{|c|}{ DLpideraloong Lto } \\
\hline Yo: & $\omega$ & 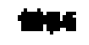 & $\mathbf{n}$ & 100 \\
\hline pł & 5 & D. & FAt & 1441 \\
\hline 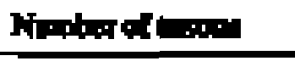 & - & $\mathbf{4}$ & 4 & $1+1$ \\
\hline Dfutity (CD) & 44 & 5 & 4 & 10 \\
\hline 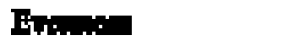 & H: & $\boldsymbol{H}$ & $\boldsymbol{T}$ & ats \\
\hline 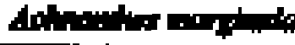 & & & & \\
\hline 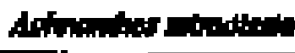 & & & & \\
\hline 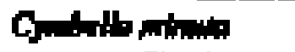 & & & & \\
\hline 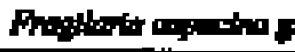 & & & & \\
\hline 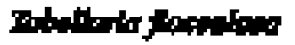 & & & & \\
\hline 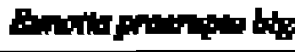 & & & & \\
\hline 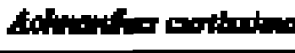 & & & & \\
\hline 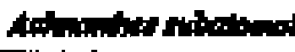 & & & & \\
\hline 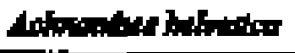 & & & & \\
\hline 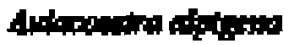 & & & & \\
\hline
\end{tabular}

Fig. 6. The structure of diatom communities of Dlugi Gasienicowy lake in the years 1993-1996; the numerous species (relative abundance $>5 \%$ ).

gered organism, included in the Red List of species (Lange-Bertalot \& Genkal 1999 ). In Zmarzły Gasienicowy lake Achnanthes marginulata was accompanied by the also fairly abundant Achnanthes helvetica which prefers circumneutral to weakly acidic environments (Krammer \& Lange-Bertalot 1991 b), and A. helvetica var. minor, another acidophilous org a $\mathrm{n}$ i s $\mathrm{m}$ (Flower \& Jones 1989).

Four years' observations of diatom communities in Dlugi Gasienicowy lake showed a stability of structure, with dominance of Achnanthes marg in u la ta, and did not indicate progress towards acidification (Fig. 5, 6), although long- term observations, made by several authors, of the $\mathrm{pH}$ of the lake water showed a small but gradual decline. Olszewski (1939) found the $\mathrm{pH}$ of the lake to be above 6 , while 30 years later Oleksynowa \& Komornicki (1989) noted a pH of 5,8. In the years 1985-1986 the mean $\mathrm{pH}$ value of the same lake was 5.6 (Wojtan \& Galas 1994), with a similar value being noted from 1993 to 1999 (The Molar Water Chemistry Group 1999). At present, the moss Warnstorfia exan nulata (Schimp.) Loeske, known for its preference in acid environments (peatbogs and swamps), is abundant on the bottom of this lake. However, the abundant development of a moss had already been noted in 1938 (Olszewski 1948). These findings therefore indicate that the intermediate acidic character of the water seems to be its constant and natural feature.

In the remaining mostly very deep lakes the circumneutral group of diatoms predominated, and among them Achnanthes minutissima, which has a wide ecological spectrum ( $\mathrm{pH} 4.3-9.2$; Lowe 1974) was numerous. It formed an especially large population in the deep Czarny pod Rysami lake, where the lowest diversity index was also recorded, which indicates some disturbance to the dominance structure of its diatom communities. 
According to its water chemistry, Dwoisty Gasienicowy lake belongs to the group of intermediately acidic lakes. Within its diatom communities the circumneutral and acidobionts were in balance, but their structure did not indicate acidification. However, the structure of the diatom communities was not stable since the results of the 1996 study showed the dominance of Achnanthes marg in ulata and Eunotia prae rupta bigibba group (Kownacki et al. 2002), which are both acidophilic organisms (Van Dam et al. 1994). This instability of its diatom community is connected with the ephemeral character of this lake from which the water disappears in winter through the underground outflow and, in spring, the lake fills again with water from the melting snow. Springtime is very important in the process of acidification, because the $\mathrm{pH}$ values drop drastically. The length of residence time is also an important factor in the acidification process (Kopáček \& Stuchlik 1994). Such lakes as D w o i s t y, Dlugi and Zmarzly Gasienicowy are especially threatened because their residence time is short and additionally they have very low alkalinity (Ta b $1 \mathrm{e}$ $1,3)$.

\section{Conclusion}

On the basis of water chemistry and diatom community structure analyses, most of 10 investigated Tatra lakes were not found to be acidified. To them belong the deep lakes where circumneutral org a $\mathrm{n}$ i s $\mathrm{m} \mathrm{s}$ prevailed, and especially Achnanthes minutissima as the dominant species. Shallow lakes (Długi and Zmarzły Gasienicowy lakes) showed a moderate level of acidification. Acidophilous species prevailed there with the Achnanthes marg in u la ta as the dominant species. Four years observations of the Dhugi lake indicate that acidification seems to be its constant feature. The diatom community structures generally confirmed the status of the studied lakes as judged from their water chemistry.

\section{Acknowledgements}

The study was financed by the Commission of the European Community within the framework of the international research projects: $\mathrm{N}^{\circ}$ EV5V-CT92 0205, $\mathrm{N}^{\circ}$ ENV4- CT95-0007 and EVK1-CT1999-00032, as well as by the Polish State Committee for Scientific Research N ${ }^{\circ}$ 6PO4F 017 13. Thanks also to Dr Janina Kwandrans (Institute of Freshwater Biology, Polish Academy of Sciences, Kraków) for diatom index calculations.

\section{References}

Bombówna M. \& Wojtan K. 1999. — Long-term changes in the chemical composition of water in some Tatra lakes. Acta Hydrobiol., 41: $1-16$
Dargocká J., Kneslová P. \& Stuchlík E. 1997. — Phytoplankton of several high mountain lakes in different stages of acidification. Studies on Tatra National Park, 2: 41-62. (in Slovak, with English summary).

Dumnicka E. \& Galas J. 2002. — Factors affecting the distribution of Oligochaeta in small high mountain ponds (Tatra Mts, Poland). Arch. Hydrobiol.,156:121-133.

Ettl M., Juriš S. \& Vranovskŷ M. 1965. - Some remarks about plankton of the mountain lakes Great and Little Hincovo Pleso in High Tatras. Zbornik TANAP., 8: 57-69. (in Slovak, with English summary).

Flower R.J. \& Jones V.J. 1989. — Taxonomic descriptions and occurrences of new Achnanthes taxa in acid lakes in the U. K. Dia tom Research, 4: 227-239.

Fott J., Prazakova M., Stuchlík E. \& Stuchlíková Z. 1994. — Acidification of lakes in Sumava (Bohemia) and in the Tatra Mountains (Slovakia). Hydrobiologia, 274: 37-47.

Fott J., Blažo M., Stuchlík E. \& Struneckŷ O. 1999. — Phytoplankton in three Tatra Mountain lakes of different acidification status. J. Limnol., 58: 107-116.

Galas J., Dumnicka E., Kawecka B., Kownacki A., Jelonek M., Stós P. \& Wojtan K.1996. — Ecosystems of some Tatra lakes - the Polish participation in the international project AL.:PE2. Pages 9699 in Kownacki A. (Ed). Tatra National Park, Nature and Man. $P$ resent state and perspectives of future Tatra investigations, Vol. 2 Biology. Tatra National Patrk, Polish Soc. of Earth Sciences, Cracow Branch, Kraków-Zakopane (in Polish with English summary).

Galas J. 2002. - Acidification state of Długi Staw Lake (High Tatra Mts) (in Polish with English summary). In: Przemiany Srodowis ka Przyrodniczego Tatr. (in press)

Juriš S. \& Kovácik L. 1987. — Beitrag zur Kenntnis des Phytoplankton der Hohen Tatra Seen (Tschechoslowakei). Zbor. Slov. nár. Múz, Prír. Ve dy, 33: 23-40. (in Slovak, with German summary).

Kawecka B. 1966. - Aufwuchsalgen auf Potamogeton sp. im See Morskie Oko. Acta Hydrobiol., 8: 321-328. (in Polish with German summary)

Kopáček J. \& Stuchlík E. 1994. — Chemical characteristics of lakes in the High Tatra Mountains, Slovakia. Hydrobiologia, 274: 49-56.

Kownacki A., Galas J., Dumnicka E.\& Mielewczyk S. 2000. — Invertebrate communities in permanent and temporary high mountain lakes (Tatra Mts). Ann. Limnol. - Int. J. Lim., 36: 181-188.

Kownacki, A., Kawecka B., Dumnicka E. \& Galas J. 2002. - Factors involved in Branchinecta paludosa O . F. Müller extinction from Tatra National Park and possibilities of its reintroduction. In Przemiany S rodowiska Przyrodniczego Ta $t r$. in Polish with English Summary (in press).

Krammer K. 1992. - Pinnularia, eine Monographie der europäischen Taxa. Bibliotheca Diatomologica, 26, Berlin-Stuttgart, 353 pp.

Krammer K \& Lange-Bertalot H. 1986. — Bacillariophyceae. Te i 1 1. Naviculaceae. in Ettl H., Gerloff J., Heynig H. \& Mollenhauer D. (Eds), Süsswasserflora von Mitteleuropa, 2/1, G. Fischer Verlag, Stuttgart-New York: 876 pp.

Krammer K \& H. Lange-Bertalot H. 1988. - Bacillariophyceae. Teil 2 Epithemiaceae, Surirellaceae. in Ettl H., Gerloff J., Heynig H. \& Mollenhauer D. (Eds), Süsswasserflora von Mitteleuro $p$ a 2/2, G. Fischer Verlag, Stuttgart-Jena, 596 pp.

Krammer K \& Lange-Bertalot H. 1991a. — Bacillariophyceae. Teil 3 Centrales, Fragilariaceae, Eunotiaceae. In: Ettl H., Gerloff J., Heynig H., Mollenhauer D. (Eds), Süsswasserflora von Mitteleu ropa, 2/3, G. Fischer Verlag, Jena, 576 pp. 
Krammer K. \& Lange-Bertalot H.1991b. — Bacillariophyceae.Teil 4 Achnanthaceae. In: Ettl H., Gärtner G., Gerloff J., Heynig H. \& Mollenhauer D. (Eds), Süsswasserflora von Mitteleuro p a 2/4, VEB G. Fischer Verlag, Stuttgart-Jena , 436 pp.

Lange-Bertalot H \& Genkal S.I. 1999. — Diatoms from Siberia I, Islands in the Arctic Ocean (Yugorsky-Shar Strait). In (H. LangeBertalot Ed.). Annotated Diatom Micrographs. PhytogeographyDiversity-Taxonomy. Iconographia Diatomologica, 6. A.R.G. Gantner Verlag K.G. 295 pp.

Lange-Bertalot H \& Moser G. 1994. - Brachysira, Monographie der Gattung. Bibliotheca Diatomologica, 29. J. Cramer, BerlinStuttgart, $212 \mathrm{pp}$.

Lange-Bertalot H \& Metzeltin D. 1996. — Indicators of oligotrophy. Iconographia Diatomologica, (H. Lange-Bertalot Ed.) 2. Koeltz Scientific Books, 390 pp.

Lange-Bertalot H, Metzeltin D. \& Witkowski A. 1996. - Hyppo donta gen. nov.: Umschreibung und Bergründung einer neuen Gattung de Naviculaceae. In: H. Lange-Bertalot, ed., Iconogra phia Diatomologica. Königstein: Koeltz Scientific Books, 4, $30 \mathrm{pp}$.

Lowe R. L. 1974. - Environmental requirements and pollution tolerance of freshwater diatoms. Cincinnati, Ohio, Nat. Environment. Res. Center Office of Develop. U.S Environm. Protect. Agency., 334 pp.

Lukavskŷ J. 1994. - Algal flora of lakes in the High Tatra Mountains (Slovakia). Hydrobiologia, 274: 65-74.

Lydersen E. Rzychoń D., Worsztynowicz A., Torseth K., Hanssen J. E., Mill A.M., Kot M., Henriksen A. \& Wathne B.M. 1997. Critical loads in lakes in the Polish Tatra Mountains. Acid Rain Research Final Report 44/1997. No rwegian Institute for Wa t e $r$ Research (NIVA), 49 pp.

Marciniak B. 1982. - Late Glacial and Holocene new diatoms from a glacial lake Przedni Staw in the Pieć Stawów Polskich Va 11 e y. Polish Tatra Mts. Acta Geol.Acad. Sci. Hung., 25 (1-2): 161-171.

Marciniak B. 1986. — Late Glacial Fragilaria from lake sediments of the Tatra Mts. and the Alps.9th Diatom-Symposium: 233-241.

Mosello R., Wathne B.M., Lien L. \& Birks H.J.B. 1995. — AL:PE projects: water chemistry and critical loads. Wa te $r$, Air and Soil Pollution, 85: 493-498.

Oleksynowa K. \& Komornicki T. 1989. — Materialy do znajomosci wód w Tatrach. VIII Dolina Suchej Wody. Zeszyty Naukowe A.R. im H. Kołłataja w Krakowie, 241, Rolnictwo, 28: 3-31.

Olszewski P. 1939. — Einige Bestimmungen zum Chemismus der Gewasser in der Umgebung der Gasienicowa-Alm (Hohe Tatra). Sprawozdania Komisji Fizjograficznej, 72:501-530. (in Polish with German summary).

Olszewski P. 1948. - Winter stratification of oxygen in the larg e r Tatra Lakes. Rozprawy Wydz. Mat.-Przyrod., 72, A: 185-265.

Pielou E.C. 1975. - Ecological diversity. J. Wiley \& Sons, Inc., New York, 165 pp.

Round F.E., Crawford R.M. \& Mann. D.G. 1990. — The Diatoms: Biology and Morphology of the Genera. Cambridge University Press. $747 \mathrm{pp}$.

Prygiel J., Whitton B.A., Bukowska J. (eds.) 1999. — Use of Algae for Monitoring Rivers. Proceedings of an International Symposium held at the Agence de L'Eau Artois-Picardie, Douai, France, 29 September - 1 October 1997, 271 pp.

Siemińska J. 1970. — Niektóre aspekty badań Morskiego Oka w Tatrach. Kosmos Ser. A, 19, 2 (103): 173-179.

Shannon C.E \& Weaver 1949. - The mathematical theory of communication. University of Illinois press, Urbana, $117 \mathrm{pp}$.

Starmach K. 1973. - Benthic algae of the Great Lake in the Valley of the Five Polish Lakes (High Tatra Mts.). Acta Hydrobiol., 10: 155-161. (in Polish with English summary)
Szklarczyk-Gazdowa C. 1960. - Phytoplankton of some Ta t r a lakes. Acta Soc. Bot. Pol., 29: 597-624. (in Polish with English summary).

Šiško M. \& Kosi G. 2002. - Algae. In: High Mountain lakes in the eastern part of the Julian Alps. (Brancelj A. Ed.), Ljubljana, 111-128.

Tolotti M. 2001. - Phytoplankton and littoral epilithic diatoms in high mountain lakes of the Adamello-Brenta Regional Park (Trentino, Italy) and their relation to trophic status and acidification risk. J. Limnol., 60: 171-188.

Tolotti M. \& Cantonati M. 2002. — Diatomee litorali. In: I Laghi del Parco Naturale Adamello-Brenta. (Cantonati M., Tolotti M. \& Lazzara M. Eds.). Strembo (TN), Giugno 2002, 201-224.

The MOLAR Water Chemistry Group 1999. — The MOLAR Project: atmospheric deposition and lake water chemistry. J. Limnol., 58: 88-106.

Van Dam H., Mertens A. \& Sinkeldam J. 1994. — A coded checklist and ecological indicator values of freshwater diatoms from the Netherlands. Neth. J. Aquat. Ecol., 28: 117-133.

Wasylik K. 1965. - Remnants of algae in bottom sediments of the lakes Wielki Staw and Morskie Oko in the Tatra Mountains. Kom. Zagospod. Ziem Górskich PAN, 11: 39-58.

Wathne B.M., Patrick S.T., Monteith D. \& Barth H. 1995. — AL:PE Project Part 1: April 1991-April 1993, Ecosystem, Research Report 9, European Commission: 292 pp.

Wathne B.M., Patrick S. \& Cameron N. 1997. — Al:PE-Acidification of Mountain Lakes: Paleolimology and Ecology. Part 2 - Remote Mountain Lakes as Indicators of Air Pollution and Climate Change. NIVA Report 3538-97, Oslo.

Wathne B.M \& Rosseland B.O. 1999. - Measuring and modelling the dynamic response of remote mountain lake ecosystems to environmental changes: A programme of Mountain Lake ResearchMOLAR, Final Report 4/1999, March 1996-March 1999 NIVA, Report 96061-1, Oslo 201 pp.

Whitton B.A., Rott E. \& Friedrich G.(eds). 1991. — Use of Algae for Monitoring Rivers. Proceedings of an International Symposium held at the Landesamt für Wasser und Abfall NordrheinWestfalen Düsseldorf, Germany, 26-28 May 1991, 193 pp.

Whitton B.A., Rott E. (eds.). 1996 - Use of Algae for Monitoring Rivers. Proceedings of an International Symposium held at the Volksbildungsheim Grillof, Vill near Innsbruck, Innsbruck, Austria, 17-19 September 1995, $196 \mathrm{pp}$.

Wołoszyńska J. 1917. — Die Algen der Tatraseen und Tümpel. I. Bull. Int. Acad. Sci. Cracovie, Cl. Sci. Math. Nat., S e r. B, 1-3: 196-200.

Wołoszyńska J. 1934. - Asterionella formosa Hass var. tatrica n . v a r. w jeziorach tatrzanskich. Acta Soc. Bot. Pol., 11 Suppl., 137-151.

Wołoszyńska J. 1935. — Die Algen der Tatraseen und Tümpel. II. Über zwei Gymnodinien aus den Seen «Morskie Oko und «Czarny Staw pod Ry s a mi ». Bull. Acad. Pol. Sci. Lettr. Cl. Sc. Math. Nat., Ser. B, (1):1-9.

Wołoszyńska J. 1936. — Die Algen der Tatraseen und Tümpel III Peridineen im Winterplankton einiger Tatraseen. Arch. Hydrobiol. i Rybactwa, 10: 188-196.

Wołoszyńska J. 1939. — Die Algen der Tatraseen und Tümpel IV. Acta Soc. Bot. Pol., 16 (1): 29-39.

Wojtan K \& Galas J. 1994. - Acidification of small mountain lakes in the High Tatra Mountains, Poland. Hydrobiologia, 274: $179-182$. 